\title{
EFISIENSI INPUT USAHATANI PADI SAWAH DI KELURAHAN TENDEADONGI KECAMATAN PAMONA UTARA
}

\author{
Input Effiency of Rice Field Farming at Tendeadongi Village \\ North Pamona District
}

Marianne Reynelda Mamondol ${ }^{1)}$

Dicy Rianto Tambe'o ${ }^{2)}$

e-mail : mariannemamondol@ymail.com

1), 2) Fakultas Pertanian Universitas Kristen Tentena

\begin{abstract}
The purpose of this study is to examine the input efficiency of rice field farming at Tendedongi Village North Pamona District in terms of technical, allocative, and economical aspects. Inputs which assumed influence rice production significantly are seed, fertilizer, and herbicide. Technical efficiency is analyzed through regression coefficient obtained by Cobb-Douglas production function modelling. Allocative or price efficiency is determined by Marginal Product Value (MPV) and Input Price (IP) ratio. Multiplication sum between technical and price efficiency constitutes economical efficiency from inputs which are used in production process. Study result demonstrates that technically, the seed applying by farmers is not efficient yet, whereas the applying of fertilizer has reached efficiency. The application of herbicide is not efficient, excessive, and its addition will reduce rice production. Price efficiency shows that variables of seed and fertilizer have not achieved efficient using and can still be enhanced to increase output and farmers' profit, otherwise herbicide variable indicates an inefficient using. In terms of economical efficiency, seed and fertilizer usings are not efficient yet as well, while herbicide using may cause inefficiency on rice production. It may be concluded that farmers need knowledge regarding good input management in terms of quantity and time for application so that farm efficiency may be achieved.
\end{abstract}

Keywords : Technical efficiency, Price efficiency, Economical efficiency, Input

\section{PENDAHULUAN}

Beras merupakan bahan makanan pokok bagi sebagian besar masyarakat Indonesia. Posisi beras sebagai bahan makanan pokok memiliki implikasi luas pada berbagai kebijakan pemerintah yang meliputi aspek politik, ekonomi, dan sosial. Secara politis pemerintah menempatkan beras sebagai komoditas bernilai strategis dalam pembangunan ekonomi, di mana salah satu target pembangunan ialah terciptanya swasembada beras (Kusnadi et al, 2011).

Sektor pertanian merupakan sektor yang memberikan kontribusi cukup besar bagi perekonomian Kabupaten Poso. Sejak tahun 2009 hingga 2012, kontribusi sektor pertanian terhadap PDRB Kabupaten Poso ialah rata-rata sebesar $44,07 \%$ di mana $13,62 \%$ di antaranya berasal dari tanaman bahan makanan berupa padi sawah dan jagung (BPS Poso, 2012).
Peran penting komoditas beras bagi perekonomian daerah perlu ditunjang melalui berbagai upaya, di antaranya ialah berupa peningkatan produksi padi. Peningkatan produksi umumnya dapat ditempuh melalui upaya ekstensifikasi dan intensifikasi. Ekstensifikasi merupakan peningkatan produksi melalui ekspansi areal penanaman, sedangkan intensifikasi berupaya untuk mengintensifkan kegiatan budidaya pada areal yang tersedia (Hanafie, 2010).

Usaha peningkatan produksi tanaman padi sawah melalui jalur ekstensifikasi tampaknya semakin sulit. Hal ini disebabkan karena semakin terbatasnya lahan pertanian produktif serta alih fungsi lahan pertanian ke penggunaan non pertanian yang sulit dibendung (Dewi et al, 2012). Karena itu, alternatif yang perlu dipertimbangkan ialah meningkatkan produksi tanaman melalui efisiensi. 
Prinsip efisiensi memberikan penekanan pada optimalisasi penggunaan faktor produksi (input) dalam proses produksi pertanian. Efisiensi dapat digolongkan menjadi 3 kategori, yaitu efisiensi teknis, efisiensi alokatif, dan efisiensi ekonomis. Efisiensi Teknis (Technical Efficiency) adalah besaran yang menunjukkan perbandingan antara produksi riil dengan produksi maksimum yang mungkin dicapai. Pada efisiensi teknis diperlihatkan kemampuan relatif dari usahatani untuk memproduksi output tertentu dengan penggunaan sejumlah input tertentu pada tingkat teknologi tertentu (Tahir et al, 2010). Efisiensi Alokatif atau Efisiensi Harga (Allocative Efficiency / Price Efficiency) menunjukkan hubungan antara biaya dan output. Efisiensi harga dapat tercapai apabila keuntungan dapat dimaksimumkan melalui perbandingan antara nilai produk marginal setiap input dengan harga input tersebut (Nguyen et al, 2012). Jika efisiensi harga diperoleh pada kondisi di mana usahatani efisien secara teknis maka Efisiensi Ekonomis (Economical Efficiency) akan tercapai (Soekartawi, 2003).

Fungsi produksi merupakan fungsi yang menjelaskan hubungan fisik antara jumlah input yang digunakan dengan jumlah output dihasilkan (Prayoga, 2010). Untuk dapat menjelaskan hubungan fisik ini, telah banyak model fungsi produksi yang dikembangkan. Salah satunya ialah fungsi produksi stochastic frontier CobbDouglas. Fungsi produksi Cobb-Douglas merupakan fungsi yang melibatkan dua atau lebih variabel, berupa variabel terikat atau output $(\mathrm{Y})$ dan variabel bebas atau input $(X)$. Fungsi produksi Cobb-Douglas memiliki beberapa keunggulan dalam studi empiris. Selain mudah digunakan karena dapat ditransformasikan ke dalam bentuk linear, fungsi ini juga sangat mudah diinterpretasikan bentuknya. Chang (2011) menyatakan bahwa fungsi produksi Cobb-Douglas merupakan bentuk fungsi yang dapat menjelaskan batas produksi deterministik sebagai hasil penerapan teknologi pada tanaman padi di Taiwan, dan penjelasan tersebut lebih baik dibandingkan dengan yang dihasilkan oleh fungsi produksi lainnya yaitu fungsi translog.
Kelurahan

Tendeadongi

merupakan salah satu areal penanaman padi sawah di Kecamatan Pamona Utara. Sebagian penduduk (25 \%) bermata pencaharian sebagai petani, dalam hal ini petani padi sawah. Pada penelitian ini, input yang diasumsikan mempengaruhi produksi padi sawah ialah benih, pupuk, dan herbisida. Ketiga macam input tersebut umumnya digunakan petani dalam proses produksi padi sawah. Menurut Pakasi et al (2011), ketersediaan input tidak selamanya memberikan produksi yang dapat menguntungkan petani. Sering ditemukan bahwa penggunaan input oleh petani tidak lagi sesuai dengan kebutuhan skala petani, padahal efisiensi sulit dipisahkan dari skala usaha (Isyanto, 2012).

Pada proses produksi, untuk memperoleh keuntungan maksimal, petani harus dapat memilih penggunaan input dengan tepat dan mengombinasikan berbagai input secara optimal dan efisien. Akan tetapi pada kenyataannya, masih banyak petani yang belum memahami penggunaan input secara efisien yang akhirnya dapat mengakibatkan produksi tanaman tidak dapat meningkat secara signifikan. Karena itu perlu dilakukan penelitian mengenai efisiensi penggunaan input oleh petani dalam kegiatan usahatani yang dilakukannya.

Berdasarkan uraian tersebut, maka rumusan masalah dalam penelitian ini ialah : Bagaimanakah efisiensi input usahatani padi sawah di Kelurahan Tendeadongi Kecamatan Pamona Utara ditinjau dari aspek teknis, alokatif, dan ekonomis?

Tujuan penelitian ini ialah untuk mengetahui efisiensi input usahatani padi sawah di Kelurahan Tendeadongi Kecamatan Pamona Utara ditinjau dari aspek teknis, alokatif, dan ekonomis. Adapun manfaat penelitian ini ialah : (1) Sebagai sumber informasi mengenai pemanfaatan input secara efisien untuk memberikan produksi tanaman padi sawah yang optimal, dan (2) Sebagai referensi bagi penelitian-penelitian selanjutnya. 
Penelitian ini dilaksanakan pada bulan April hingga Juni 2013, bertempat di Kelurahan Tendeadongi Kecamatan Pamona Utara. Data yang digunakan dalam penelitian ini ialah berupa data primer yang diperoleh melalui wawancara dengan responden penelitian. Data primer yang dikumpulkan meliputi produksi padi, kuantitas penggunaan input benih, pupuk, dan herbisida, serta harga setiap jenis input.

Populasi penelitian ialah petani padi sawah di Kelurahan Tendeadongi yang berada di areal irigasi teknis dengan jumlah 25 orang. Penetapan populasi pada areal tersebut dimaksudkan untuk meminimalkan pengaruh faktor luar terutama air sehingga hanya ketiga jenis input yang dimasukkan ke model fungsi produksi yaitu benih, pupuk, dan herbisida yang diasumsikan mempengaruhi produksi padi sawah. Dari populasi tersebut seluruh elemen diambil sebagai sampel penelitian melalui teknik total sampling, sehingga nilai-nilai yang diperoleh mencerminkan karakteristik populasi yang sebenarnya (true value).

Variabel-variabel yang digunakan dalam penelitian ini ialah : (1) Produksi padi sawah, yaitu hasil gabah kering giling per musim tanam (kg), (2) Jumlah benih, yaitu jumlah benih yang digunakan sebagai bahan tanaman per musim tanam (kg), (3) Jumlah pupuk, yaitu jumlah pupuk yang digunakan dalam produksi per musim tanam $(\mathrm{kg})$, (4) Jumlah herbisida, yaitu jumlah herbisida yang digunakan dalam produksi per musim tanam (liter), (5) Harga benih, yaitu harga pembelian benih per unit (Rp/kg), (6) Harga pupuk, yaitu harga pembelian pupuk per unit (Rp/kg), dan (7) Harga herbisida, yaitu harga pembelian herbisida per unit (Rp/liter).

Teknik analisis data yang digunakan dalam penelitian ini ialah :

\section{Perhitungan Efisiensi Teknis}

Efisiensi teknis ditentukan dengan menggunakan fungsi produksi CobbDouglas sebagai berikut :

$$
\begin{aligned}
& \quad \mathrm{Y}=\mathrm{a} X_{1}^{b_{1}} X_{2}^{b_{2}} X_{3}^{b_{3}} \\
& \quad \mathrm{Y}=\log \mathrm{a}+\mathrm{b}_{1} \log \mathrm{X}_{1}+\mathrm{b}_{2} \log \\
& \mathrm{X}_{2}+\mathrm{b}_{3} \log \mathrm{X}_{3} \\
& \text { Keterangan : } \\
& \mathrm{Y} \quad=\text { Produksi padi (kg/musim tanam) }
\end{aligned}
$$

$\begin{array}{ll}\mathrm{a} & =\text { Konstanta } \\ \mathrm{b}_{1} & =\text { Elastisitas input variabel benih } \\ \mathrm{X}_{1} & =\text { Jumlah penggunaan benih }\end{array}$ ( $\mathrm{kg} /$ musim tanam)

$\mathrm{b}_{2} \quad=$ Elastisitas input variabel pupuk

$\mathrm{X}_{2}=$ Jumlah penggunaan pupuk ( $\mathrm{kg} /$ musim tanam)

$\mathrm{b}_{3}=$ Elastisitas input variabel herbisida

$\mathrm{X}_{3}=$ Jumlah penggunaan herbisida (liter/musim tanam)

Pengujian kebermaknaan masingmasing parameter regresi pada model tersebut dilakukan dengan menggunakan uji $t 1$ sampel dengan rumus sebagai berikut :

$$
\mathrm{t}=\frac{\dot{x}-\mu_{0}}{\frac{s}{\sqrt{n}}}
$$

Keterangan :

$$
\begin{array}{ll}
\mathrm{t} & =\text { Nilai } \mathrm{t} \text { hitung } \\
\dot{x} & =\text { Rata-rata } \mathrm{x}_{\mathrm{i}} \\
\mu_{0} & =\text { Nilai yang dihipotesiskan } \\
\mathrm{s} & =\text { Simpangan baku } \\
\mathrm{n} & =\text { Jumlah anggota sampel }
\end{array}
$$

Nilai $b>1$ menunjukkan bahwa penggunaan input berada pada daerah produksi I. Pada daerah ini penambahan input sebesar $1 \%$ akan menyebabkan penambahan produksi lebih besar daripada $1 \%$. Pada kondisi ini penggunaan input belum efisien, sehingga produsen masih dapat memperbesar pendapatan dengan melakukan penambahan pemakaian input.

Nilai $b=1$ menunjukkan bahwa penggunaan input berada pada daerah produksi II. Pada daerah ini penambahan input sebesar $1 \%$ akan menyebabkan penambahan produksi antara 0 dan $1 \%$. Pada kondisi ini penggunaan input telah efisien sehingga bisa dicapai produksi dan keuntungan yang maksimum.

Nilai $b<1$ menunjukkan penggunaan input berada pada daerah produksi III. Pada daerah ini penambahan input akan menurunkan produksi. Pada kondisi ini penggunaan input tidak lagi efisien bahkan cenderung berlebihan, sehingga perlu dikurangi.

\section{Perhitungan Efisiensi Harga}

Efisiensi harga ditentukan dengan menghitung nisbah antara Nilai Produk Marjinal (NPM) dengan Harga Input (HI). 
Rumus untuk menentukan Nilai Produk Marjinal (NPM) ialah sebagai berikut :

$$
\mathrm{NPM}=\frac{b \cdot Y \cdot P_{y}}{X}
$$

Keterangan :

NPM = Nilai Produk Marjinal

$\mathrm{b}=$ Elastisitas input

$\mathrm{Y} \quad=$ Produksi

Py $\quad=$ Harga produksi

$\mathrm{X} \quad=$ Jumlah input

Nisbah NPM / HI > 1 menunjukkan

bahwa penggunaan input $X$ dianggap belum efisien, input $X$ masih dapat ditambahkan sehingga pendapatan masih dapat diperbesar. Nisbah NPM / $\mathrm{HI}=1$ menunjukkan bahwa penggunaan input $X$ efisien, sedangkan nisbah NPM / HFP $<1$ menunjukkan bahwa penggunaan input $X$ tidak efisien dan perlu dikurangi.

\section{Perhitungan Efisiensi Ekonomis}

Efisiensi ekonomis ditentukan dengan menggunakan rumus sebagai berikut :

$$
\mathrm{EE}=\mathrm{ET} . \mathrm{EH}
$$

Keterangan :

$\mathrm{EE} \quad=$ Efisiensi Ekonomis

ET = Efisiensi Teknis

$\mathrm{EH}=$ Efisiensi Harga

Nilai EE > 1 menunjukkan bahwa penggunaan input $X$ dianggap belum efisien secara ekonomis, karena itu penggunaannya masih dapat ditambahkan untuk meningkatkan pendapatan. Nilai EE $=1$ menunjukkan bahwa penggunaan input $X$ efisien secara ekonomis, sedangkan nilai $\mathrm{EE}<1$ menunjukkan bahwa penggunaan input $X$ tidak efisien secara ekonomis dan perlu dikurangi.

\section{HASIL DAN PEMBAHASAN}

\section{Keadaan Usahatani}

1) Lahan

Luas lahan yang dikelola petani dapat dilihat pada Tabel 1 sebagai berikut :

Tabel 1. Luas Lahan Petani Responden Penelitian

\begin{tabular}{llll}
\hline No. & Luas Lahan (ha) & Jumlah Petani (org) & $\%$ \\
\hline 1. & $<0,10$ & - & 0 \\
2. & $0,10-0,19$ & 4 & 16 \\
3. & $0,20-0,29$ & 19 & 76 \\
4. & $0,30-0,39$ & 1 & 4 \\
5. & $0,40-0,49$ & 1 & 4 \\
6. & $\geq 0,50$ & - & 0 \\
\hline & Jumlah & 25 & 100 \\
\hline
\end{tabular}

Sumber : Diolah dari data primer, 2013

Tabel 1 memperlihatkan bahwa luas lahan terbanyak yang diusahakan petani responden $(76 \%)$ ialah berada pada kisaran $0,20-0,29$ ha. Lahan yang dikelola oleh semua petani responden merupakan lahan milik pribadi (Tambe'o, 2012). Walaupun demikian secara umum dapat dikatakan bahwa berdasarkan skala usahatani, usahatani padi sawah yang dikelola oleh petani responden merupakan usahatani berlahan sempit karena luasnya yang kurang dari 0,5 ha (Suratiyah, 2008). Usahatani berlahan sempit umumnya inefisien secara ekonomis serta sangat rentan terhadap pengaruh kondisi alam yang ekstrem dan desakan ekonomi. Anomali cuaca, bencana alam, serangan hama dan penyakit yang tidak mampu ditanggulangi petani, atau kebutuhan ekonomi yang mendesak dapat membuat kepemilikan lahan beralih dari petani pemilik kepada pihak lain.

2) Penggunaan Input Penggunaan input oleh petani responden dapat dilihat pada Tabel 2 sebagai berikut : 
Tabel 2. Rata-rata Penggunaan Input oleh Petani Responden Penelitian

\begin{tabular}{llll}
\hline No. & Jenis Input & Spesifikasi & Rata-rata Penggunaan \\
\hline 1. & Benih & Benih Tidak Bersertifikat (F2) & $23,08 \mathrm{~kg}$ \\
2. & Pupuk & Ponska & $79,80 \mathrm{~kg}$ \\
3. & Herbisida & Clipper & 0,39 liter \\
\hline
\end{tabular}

Sumber : Diolah dari data primer, 2013

Benih yang digunakan oleh petani responden merupakan benih tidak bersertifikat yang berasal dari hasil panen musim tanam sebelumnya. Hasil panen umumnya dikonsumsi oleh petani dan keluarga, dijual, dan sebagian disimpan untuk dijadikan benih pada musim tanam berikut. Pupuk yang digunakan ialah berupa Ponska dengan dosis yang umumnya ditentukan sendiri oleh petani berdasarkan pengalaman berusahatani padi sawah. Herbisida yang digunakan ialah herbisida bermerk dagang Clipper yang digunakan untuk mengendalikan populasi gulma pada pertanaman padi sawah. Konsentrasi yang digunakan disesuaikan dengan kondisi kerapatan gulma yang terdapat pada areal pertanaman.

\section{Analisis Efisiensi Input Usahatani Padi Sawah}

1) Efisiensi Teknis Penggunaan Input pada Usahatani Padi Sawah

Berdasarkan hasil analisis fungsi produksi Cobb-Douglas diperoleh model hubungan antara produksi padi sawah dengan input benih, pupuk, dan herbisida sebagai berikut :

$$
Y=1692,708 X_{1}^{1,318} X_{2}{ }^{0,946} X_{3}^{-3,106}
$$

Hasil uji kebermaknaan setiap parameter regresi pada taraf signifikansi $5 \%$ dapat dilihat pada Tabel 4 sebagai berikut :

Tabel 3. Hasil Uji Kebermaknaan Parameter Regresi

\begin{tabular}{llllll}
\hline No & Prediktor & Koefisien Regresi & t hitung & t tabel & Keterangan \\
\hline 1. & Benih & 1,318 & & & \\
2. & Pupuk & 0,946 & $22,495^{*}$ & 1,711 & Signifikan \\
3. & Herbisida & $-3,106$ & $10,204^{*}$ & & Signifikan \\
\hline
\end{tabular}

Keterangan : ${ }^{*}=$ berpengaruh nyata pada $\alpha=5 \%$

Input benih berpengaruh secara signifikan pada produksi padi sawah. Nilai koefisien regresi input benih sebesar 1,318 menunjukkan bahwa penggunaan benih berada pada daerah produksi I, artinya bahwa jika benih ditambahkan sebesar $1 \%$ maka produksi padi sawah akan meningkat sebesar $1,318 \%$. Penggunaan input benih belum efisien, jadi masih dapat ditambahkan jumlahnya untuk meningkatkan produksi dan pendapatan petani. Penggunaan benih pada petani responden berkisar antara 15 - $40 \mathrm{~kg}$ pada lahan dengan luas antara $0,15-0,40$ ha. Artinya bahwa kebutuhan benih belum mencukupi bagi lahan yang sawah yang diusahakan petani. Apalagi mengingat bahwa benih yang diusahakan petani merupakan benih tidak bersertifikat yang tidak memiliki jaminan keseragaman viabilitas, daya kecambah, maupun daya tumbuh. Karenanya penggunaan benih bersertifikat dapat menjadi alternatif bagi petani untuk meningkatkan efisiensi usahatani padi sawah.

Penggunaan input pupuk berpengaruh signifikan terhadap produksi padi sawah. Nilai koefisien regresi pupuk sebesar 0,946 menunjukkan bahwa pemakaian pupuk efisien karena elastisitas inputnya berada pada daerah produksi II. Penambahan pupuk sebesar $1 \%$ menyebabkan peningkatan produksi sebesar 0,946 \%. Dosis pupuk Ponska yang digunakan petani responden berkisar antara 35 - $200 \mathrm{~kg}$ pada lahan dengan luas antara 0,15 - 0,40 ha, atau jika dikonversi maka dapat dihitung bahwa penggunaan pupuk oleh petani berkisar antara 233,33 kg/ha - $500 \mathrm{~kg} / \mathrm{ha}$. Pemakaian pupuk sebenarnya disesuaikan dengan ketersediaan hara tanah, karena itu analisis kesuburan tanah diperlukan untuk dapat 
merekomendasikan penggunaan pupuk dengan dosis yang tepat. Aplikasi pupuk organik sebagai alternatif pupuk kimia sintetik juga dapat menjadi alternatif bagi petani untuk peningkatan efisiensi serta terciptanya model pertanian yang ramah lingkungan.

Input herbisida juga memberikan pengaruh signifikan pada produksi padi sawah. Nilai koefisien regresi herbisida sebesar -3,106 menunjukkan penggunaan input yang berlebihan dan tidak efisien, yang letaknya pada daerah produksi III. Penambahan herbisida sebesar $1 \%$ akan menyebabkan turunnya produksi padi sawah sebesar $\quad 3,106 \%$. Herbisida digunakan oleh petani responden dengan kisaran dosis $0,10-0,50$ liter/areal pertanaman atau 0,67 liter/ha - 1,25 liter/ha. Jumlah tersebut menyebabkan terjadinya inefisiensi pada usahatani, karena penurunan produksi yang diakibatkan penambahan pemakaian herbisida dapat berakibat pada menurunnya pendapatan yang diperoleh petani.

2) Efisiensi Harga Penggunaan Input pada Usahatani Padi Sawah

Perhitungan nisbah antara Nilai Produk Marjinal (NPM) dengan Harga Input (HI) diperlihatkan pada Tabel 5 sebagai berikut :

Tabel 4. Nisbah NPM / HI pada Usahatani Padi Sawah

\begin{tabular}{lllll}
\hline Input & $\begin{array}{l}\text { HI } \\
\text { (Rp/unit) }\end{array}$ & NPM & Nisbah NPM / HI & Keterangan \\
\hline Benih & $5.000,-$ & $821.134,558$ & 164,227 & Belum Efisien \\
Pupuk & $2.250,-$ & $170.460,191$ & 75,760 & Belum Efisien \\
Herbisida & $35.000,-$ & $-114.517 .423,600$ & $-3.271,926$ & Tidak Efisien \\
\hline
\end{tabular}

Hasil perhitungan menunjukkan bahwa ditinjau dari efisiensi harga, penggunaan input benih dan pupuk belum mencapai efisiensi. Hal tersebut ditunjukkan dari nisbah NPM/HI yang nilainya lebih besar daripada 1 . Penambahan pengadaan kedua jenis input tersebut masih dapat dilakukan apabila petani masih ingin memperbesar keuntungan usahataninya. Sebaliknya penggunaan input herbisida bersifat tidak efisien yang ditunjukkan dari nisbah
NPM/HI yang bernilai negatif. Penambahan pengadaan herbisida dapat mengurangi keuntungan usahatani padi sawah, terutama karena disebabkan tingginya harga herbisida kimia sintetik di pasaran.

3) Efisiensi Ekonomis Penggunaan Input pada Usahatani Padi Sawah

Perhitungan efisiensi ekonomis penggunaan input diperlihatkan pada Tabel 6 sebagai berikut :

Tabel 5. Efisiensi Ekonomis Penggunaan Input pada Usahatani Padi Sawah

\begin{tabular}{llllll}
\hline No. & Input & ET & EH & EE & Keterangan \\
\hline 1. & Benih & 1,318 & 164,227 & 216,451 & Belum Efisien \\
2. & Pupuk & 0,946 & 75,760 & 71,669 & Belum Efisien \\
3. & Herbisida & $-3,106$ & $-3.271,926$ & $-10.162,602$ & Tidak Efisien \\
\hline
\end{tabular}

Berdasarkan hasil perhitungan dapat diketahui bahwa penggunaan input benih dan pupuk belum mencapai efisiensi secara ekonomis, sedangkan penggunaan input herbisida tidak efisien secara ekonomis. Input-input yang belum efisien secara ekonomis merupakan input yang penggunaannya belum optimal sehingga belum memberikan keuntungan ekonomi yang maksimal. Sebaliknya input yang tidak efisien merupakan input yang tidak lagi digunakan secara optimal sehingga justru menurunkan perolehan keuntungan petani. Khai et al (2011) menyatakan bahwa efisiensi ekonomis sangat terkait dengan kemampuan petani menggunakan input dalam proporsi yang optimal disertai pertimbangan akan harga input dimaksud. Karena itu, setiap input perlu dikelola secara tepat, dalam hal ini penggunaan input dilakukan pada waktu dan kuantitas yang tepat sesuai kebutuhan. 


\section{KESIMPULAN DAN SARAN}

\section{Kesimpulan}

Analisis efisiensi teknis melalui aplikasi fungsi produksi Cobb-Douglas memperlihatkan bahwa pada usahatani padi sawah di Kelurahan Tendeadongi Kecamatan Pamona Utara, penggunaan input benih belum efisien, penggunaan input pupuk efisien, sedangkan penggunaan input herbisida tidak efisien. Ditinjau dari efisiensi harga melalui perhitungan nisbah NPM / HI, pemakaian input benih dan pupuk belum mencapai efisiensi, sementara pemakaian input herbisida tidak efisien. Penggunaan input benih dan pupuk juga belum mencapai efisiensi ekonomis, sebaliknya penggunaan input herbisida tidak efisien secara ekonomis.

\section{Saran}

Diperlukan penelitian lanjutan dengan memasukkan variabel-variabel bebas lainnya ke dalam model fungsi produksi agar kajiannya menjadi lebih komprehensif.

\section{DAFTAR PUSTAKA}

BPS Poso, 2012. Kabupaten Poso Dalam Angka 2012. Poso : Badan Pusat Statistik.

Chang, H.H. and F.I. Wen, 2011. Off-Farm Work, Technical Efficiency, and Rice Production Risk in Taiwan. Journal of Agricultural Economics. 42 (2011) : $269-278$.

Dewi, I.G.A.C., I.K. Suamba, dan I.G.A.A. Ambarawati. Analisis Efisiensi Usahatani Padi Sawah (Studi Kasus di Subak Pacung Babakan, Kecamatan Mengwi, Kabupaten Badung). E-Journal Agribisnis dan Agrowisata Fakultas Pertanian Universitas Udayana. 1 (1) : 1 10.

Hanafie, R., 2010. Pengantar Ekonomi Pertanian. Yogyakarta : Penerbit Andi.
Isyanto, A.Y., 2012. Faktor-faktor yang Berpengaruh Terhadap Produksi pada Usahatani Padi di Kabupaten Ciamis. Jurnal Cakrawala Galuh. $1(8): 1-7$.

Khai, H.V. and M. Yabe, 2011. Technical Efficiency Analysis of Rice Production in Vietnam. Journal of ISSAAS. 17 (1) : $135-146$.

Kusnadi, N., N. Tinaprilla, S.H. Susilowati, dan A. Purwoto, 2011. Analisis Efisiensi Usahatani Padi di Beberapa Sentra Produksi Padi di Indonesia. Jurnal Agro Ekonomi. $29(1): 25-48$.

Nguyen, T.T., V.N. Hoang, and B. Seo, 2012. Cost and Environmental Efficiency of Rice Farms in South Korea. Journal of Agricultural Economics. 43 (2012) : 367 - 376.

Pakasi, C.B.D., L. Pangemanan, J.R. Mandei, dan N.N.I. Rompas, 2011. Efisiensi Penggunaan Faktor Produksi pada Usahatani Jagung di Kecamatan Remboken Kabupaten Minahasa (Studi Perbandingan Peserta dan Bukan Peserta Sekolah Lapang Pengelolaan Tanaman Terpadu). Jurnal Agri-Sosial Ekonomi Fakultas Pertanian Universitas Sam Ratulangi. 7 (2) : 51 - 60.

Prayoga, A., 2010. Produktivitas dan Efisiensi Teknis Usahatani Padi Organik Lahan Sawah. Jurnal Agro Ekonomi. 28 (1) : 1 - 19.

Soekartawi. 2003. Teori Ekonomi Produksi dengan Pokok Bahasan Analisis Fungsi Cobb-Douglas. Jakarta : Raja Grafindo Persada.

Suratiyah, K. 2008. IImu Usahatani. Jakarta : Penebar Swadaya.

Tahir, A.G., D.H. Darwanto, J.H. Mulyo, dan Jamhari, 2010. Analisis Efisiensi Produksi Sistem Usahatani Kedelai di Sulawesi Selatan. Jurnal Agro Ekonomi. 28 (2) : 133 - 151. 
Jurnal Envira Volume 1 Nomor 1 Juni 2016 (hal 47-54)

Tambe'o, D.R., 2012. Pengaruh Input Terhadap Produksi Padi Sawah di Daerah Irigasi Kelurahan Tendeadongi Kecamatan Pamona Utara Kabupaten Poso. Skripsi. Tidak Dipublikasikan. Tentena : Program Strata Satu Universitas Kristen Tentena. 